\title{
Power in Global Nutrition Governance
}

\section{A Critical Analysis of the Establishment of the Scaling Up Nutrition (SUN) Partnership}

Ann Louise Lie, Centre for Development and the Environment, University of Oslo

\begin{abstract}
Global public-private partnerships for health and nutrition have proliferated since the 1990sa trend raising important questions about authority and legitimacy in global governance. Yet within the fields of international relations and public health, there has been only limited empirical research into the global politics and power dynamics behind such partnerships. This article explores how and why the Scaling Up Nutrition partnership was established. Drawing on interviews, observations, and document analysis, it demonstrates how public and private actors exercise combinations of instrumental, structural, and discursive power to normalize and institutionalize their interests and values at the global level. The study highlights as such the complexities behind the increased privatization of global nutrition governance and the importance of power analysis to uncover the normative contestations and asymmetries of power behind global partnership creation.
\end{abstract}

Keywords: Power, nutrition, global governance, public-private partnerships 


\section{Introduction}

Since the 1990s, various forms of global public-private partnerships (GPPPs) have proliferated, complementing traditional multilateral processes of global governance. This proliferation has been particularly pronounced in global health, including nutrition, providing the private sector with considerable political influence. ${ }^{1}$ One of the largest partnerships in nutrition is the Scaling Up Nutrition (SUN) Movement that has been described as "an example for ways in which, over time, the Sustainable Development Goals can best be implemented."2 Since its establishment in 2010, SUN has grown from being a loose platform of cooperation between state and nonstate actors in the area of child undernutrition to becoming an increasingly institutionalized GPPP, with its own secretariat and executive committee, working toward ending child malnutrition globally and within its sixty developing country members. In addition to its member countries, SUN's partners involve hundreds of civil society organizations and businesses, philanthropic foundations, bilateral donors, and all the main UN agencies involved in food and health. It aims to see the establishment of multistakeholder partnerships for nutrition within its member countries and focuses its work around advocacy, capacity building, and resource mobilization. ${ }^{3}$

While GPPPs are promoted as necessary and effective mechanisms to solve development challenges, they reflect a shift in authority away from states in favor of nonstate actors, raising issues about legitimacy. In global health, critics argue that their proliferation has increased fragmentation and advanced the special interests of powerful private actors, such as philanthropic foundations and corporations, thereby undermining democratic governance and

1. Andonova 2017; Youde 2017; Clapp and Scrinis 2016.

2. Nabarro 2016.

3. SUN 2016. 
challenging the authority of organizations like the UN. ${ }^{4}$ The increased agenda-setting power of private actors has also shifted priorities away from addressing complex health issues rooted in political and socioeconomic inequities, toward quick fixes and market-based technological solutions. $^{5}$

SUN claims to address many of these criticisms. It describes itself as a collective "country-led" effort that promotes a comprehensive approach to nutrition, seeking to reduce fragmentation in global nutrition governance. ${ }^{6}$ Despite its broad membership, SUN's establishment provoked considerable contestation within the international nutrition community. Certain actors still contest its legitimacy and describe it as a donor-driven and top-down initiative. ${ }^{7}$ Others again see it as a corporate-led platform used by multinational businesses to push for market-based solutions to nutrition problems. ${ }^{8}$

The purpose of this article is to examine how and why SUN came about, focusing particularly on the power, interests, and normative beliefs that shaped SUN's formation. So far, few studies have demonstrated the importance of power relationships in global health governance. ${ }^{9}$ According to Preslava Stoeva, the broad variety of actors, public and private, involved in the politics of global public health makes it a field particularly predisposed for power struggles and conflicting interests. ${ }^{10}$ This also holds for nutrition where the multisectoriality of the issue (involving sectors such as health, agriculture, food, sanitation, and environment) has led to a leadership vacuum, nationally and at the global level. The lack of an

4. Richter 2004; Utting and Zammit 2009; Harman 2016.

5. Storeng and Behague 2016.

6. Mokoro 2015a, 7.

7. Schuftan and Greiner 2013.

8. McKeon 2017; Valente 2016.

9. Stoeva 2016.

10. Stoeva 2016, 100. 
institutional home for nutrition has made the issue prone to conflicts and power struggles between a broad variety of actors. ${ }^{11}$

Nevertheless, few empirical studies of global health within international relations (IR) critically explore sources of power among nonstate actors and few analyze how power asymmetries shape identities, interests, values, and norms. Meanwhile, public health scholars pay little attention to the political character of global health institutions. While some studies apply various public policy frameworks to explain how actor power, political context, and ideas shape health agendas and policies, ${ }^{12}$ these studies often focus on the domestic level and on policy implementation processes in developing countries, leaving global power dynamics relatively unscrutinized. Similarly, most studies of nutrition partnerships assess short-term opportunities, benefits, and challenges, often at country level, rather than examining power dynamics and politics. ${ }^{13}$ While some recent studies, which explore the emergence and influence of global health networks, recognize the importance of power, they do not explicitly engage with theories of power. ${ }^{14}$

In this article, I address this gap in the literature by applying a multidimensional power framework to understand how public and private, state and nonstate actors shaped SUN's development though the exercise of instrumental, structural, and discursive power. By paying attention to the different types of power at play, I reveal the complexity and multifaceted ways that global actors seek to influence global policy processes and, hence, shape norms and institutions at the global level. I ask: Which kinds of power, interests, and normative beliefs drove SUN's formation and how were these distributed and contested between the actors

11. Nisbett et al. 2014, 423.

12. Shiffman and Smith 2007; Nisbett et al. 2014.

13. Kraak et al. 2011; Hoddinot, Gillespie, and Sivan 2015.

14. Sandberg, Andresen, and Bjune 2010; McDougall 2016; Storeng and Behague 2016; Shiffman et al. 2016. 
involved? How did the process shape what SUN is today and its role within global nutrition governance?

My findings show that SUN's rhetoric of collaboration and country leadership masks normative disagreements and power asymmetries shaping its development. SUN was the outcome of an intense power struggle between two global coalitions of state and nonstate actors with competing interests and normative views on how undernutrition should be solved, and how authority should be exercised at the global level. The instrumental power of the most resourceful coalition was effectively translated into structural and discursive power, serving to establish SUN as a GPPP, rather than as a UN-led entity with limited private sector involvement. Whether SUN has reduced fragmentation within global nutrition governance is questionable as its establishment increased the number of global coordinating entities for nutrition, strengthened divisions within civil society, and blurred responsibilities between public and private actors in the field. Contrary to its claim of being country led, developing countries had little influence over SUN's development. Over time, their influence has increased, but powerful actors from the investment coalition still dominate its governance. As critics suggest, SUN has certainly opened the space for private sector influence in global nutrition governance and is today contributing to the promotion of market- and technology-based solutions to nutrition problems. While corporate actors were not the main drivers of SUN, states, international organizations, and private actors supporting private sector involvement in global governance stood behind its creation. This mirrors developments of other GPPPs and exemplifies the complexities behind the increased institutionalization of private sector interests within global governance.

In the rest of this article, I first set out my theoretical framework and methodology before I illustrate in the empirical section how public and private actors exercised different types of power to advance their interests in the processes leading up to SUN's establishment. 


\section{Instrumental, Structural, and Discursive Power in Global Governance}

Doris Fuchs defines power in terms of actors' ability to successfully pursue a desired political objective. ${ }^{15}$ Within IR research, a power-based perspective on the role of nonstate actors in processes of global governance recognizes that power can be derived from a variety of sources that can be expressed at different levels and take on a range of forms. ${ }^{16} \mathrm{I}$ draw on a multidimensional theoretical power framework distinguishing between instrumental, structural, and discursive power. ${ }^{17}$ This distinction allows me to analyze both direct observable relationships of power between actors, often facilitated by material resources, and more indirect forms of power expressed through discursive approaches or as a consequence of the structural context in which actors operate. This framework also acknowledges the complex interaction between different types of power, and how power combinations translate into political influence.

Instrumental power refers to the direct power of one actor over another to affect political outcomes or policies. ${ }^{18}$ This power is often derived from actor-specific material resources such as finance, information, technology, and human resources. Instrumental power can be brought to bear through financing political campaigns, lobbying, and participating in PPPs to provide influence in policymaking. ${ }^{19}$ Instrumental power can also be exerted through the financing of knowledge production on which politicians or others base their decisions. Global health research has drawn attention to how private foundations use their economic resources to create

15. Fuchs 2005.

16. Barnett and Duvall 2005; Clapp and Fuchs 2009.

17. Fuchs 2005.

18. Fuchs 2005.

19. Fuchs 2005. 
evidence in support of their agendas-for instance, through funding research published in highly influential and authoritative academic journals. ${ }^{20}$

Structural power reflects the ability of actors to shape political agendas by virtue of governments' or other actors' dependence on their material resources, such as investments, expertise, or funding, but also as a consequence of the actors' positions within institutional processes. $^{21}$ With governments and international organizations increasingly dependent on external funding and expertise, private actors increasingly shape political agendas. ${ }^{22}$ In 2016 , the Bill and Melinda Gates Foundation (Gates Foundation) was the second-largest donor (after the United States) to the World Health Organization (WHO), endowing it with considerable agenda-setting power. ${ }^{23}$ Actors can also exercise structural power by influencing actual rule making. The proliferation of GPPPs is a case in point, providing private actors with the ability to adopt, implement, and enforce rules and standards, effectively replacing those holding formal decision-making power. The Gates Foundation has been particularly instrumental in establishing a number of health GPPPs, thus opening up the space for private sector influence in global health agenda setting and decision-making. ${ }^{24}$

Discursive power can be described as a "function of norms, ideas, and societal institutions," reflected in "discourse, communicative practices and cultural values." ${ }^{25}$ Through discursive framing, actors can shape perceptions, identities, norms, and ideas, and effectively influence how policy problems and solutions are framed, and what type of knowledge is

20. Shiffman 2014, 297-299.

21. Fuchs 2005.

22. Partzsch and Fuchs 2012.

23. Harman 2016

24. Partzsch and Fuchs 2012.

25. Fuchs and Lederer 2007, 8. 
perceived as truth. Increasingly, actors derive power and influence from their claims to scientific knowledge and evidence presented to policymakers. ${ }^{26}$ In the field of nutrition, for example, the food industry has been instrumental in framing the understanding of undernutrition in developing countries as a problem of missing nutrients, requiring marketbased solutions such as distribution of supplements and fortified food. ${ }^{27}$ According to Doris Fuchs and Katharina Glaab, knowledge based on economic and scientific findings has particularly strong power of interpretation in public debate, stemming from the high prestige of scientific expertise and objectivity. ${ }^{28}$

The analytical distinction between these different types of power helps to illuminate both the visible and less visible ways in which actors gain power and influence in global governance. However, in reality, these forms of power interact and reinforce each other in complex ways, as the analysis of SUN's establishment illustrates.

\section{Methodology}

I used a process-tracing methodology to illuminate the underlying processes and mechanisms at work during the period of SUN's establishment between 2005 and 2010. The analysis relies on four types of sources: thirty-two semistructured interviews with key senior officials; observations at SUN meetings and conferences (carried out between 2014 and 2017); unpublished and published documentation provided by SUN stakeholders such as meeting minutes, email correspondence, letters, and financial reports; and academic publications. The interviewees were either directly or indirectly involved in the processes leading up to the

26. Hanefeld and Walt 2015.

27. Clapp and Scrinis 2016.

28. Fuchs and Glaab 2011, 732. 
establishment of SUN, or involved with SUN's current activities. They held important roles, representing UN agencies, civil society organizations and nutrition researchers, multilateral and private donors, businesses, the SUN secretariat, external consultants involved in SUN's work, and SUN member countries. ${ }^{29}$ A number of informal conversations with actors currently or previously involved with SUN also took place at international nutrition conferences and at various SUN meetings and events such as at the Second International Conference on Nutrition in Rome in 2014 and the SUN Global Gathering in Milan in 2015. Information was also acquired through email exchanges, during a two-week visit at the SUN secretariat in Geneva in November 2015, and during an internship at the WHO's Department of Nutrition for Health and Development in September-November 2016. To limit historical errors due to recall bias among interviewees, information was triangulated among sources, both through interviews and document analysis.

\section{The Emergence of the SUN Movement}

Going behind the scenes of SUN's development, in the following section I demonstrate how the process was highly political, involving strong contestation between two coalitions of actors with conflicting norms, values, and interests with regard to global nutrition governance.

4.1 Setting the Agenda: The Micronutrient Investments versus the Human Rights to Nutrition Coalitions

While SUN was established in 2010, the processes leading up to its establishment can be traced back to the early 2000s when a number of new global actors entered the field of nutrition and

29. I obtained interviewees' informed consent. They have been anonymized to varying degrees according to their own requests. 
the problem of child undernutrition gained political attention at the global level. Studies demonstrating the economic consequences of child malnutrition and the cost effectiveness of interventions to alleviate micronutrient deficiencies helped spark global attention to the issue. ${ }^{30}$ The low cost of provision of micronutrients and promise of quick visible results was attractive to governments as well as private donors, and promised a role for the food industry in providing the technical solutions. In 2002 a GPPP, the Global Alliance for Improved Nutrition (GAIN), was established, effectively strengthening the influence of big food corporations to promote their solutions to policymakers. The aim of GAIN was to leverage "cost-effective food fortification initiatives to improve health, cognitive development and productivity in developing nations." ${ }^{31}$ In 2005, a GAIN Business Alliance for Food Fortification was established aiming to create an "enabling environment" for market solutions to malnutrition challenges. ${ }^{32}$ The main driver and funder of GAIN, as of many other health GPPPs, was the Gates Foundation, the largest private donor in global health and a strong promoter of technology-driven development. ${ }^{33}$ Similar to other GPPPs that the Gates Foundation had helped form, the World Bank became the trustee of GAIN and the other main seed funders were major bilateral donors such as the United States and Canada. ${ }^{34}$

At the time, economic and scientifically grounded research by authoritative bodies underpinned a technical approach and instrumental framing of child undernutrition. In 2004 the Copenhagen Consensus Report, undertaken by development economists, concluded that

30. See, for example, Haddad et al. 2003; Gillespie, McLachlan, and Shrimpton 2003.

31. UN Department of Public Information 2002.

32. Clapp and Scrinis 2016.

33. Fejerskov 2017.

34. WHO 2003. 
nutrition interventions were among the most cost-effective interventions in development, ${ }^{35}$ giving donors further impetus to scale up nutrition investments. The study was followed by the World Bank’s 2006 report “Repositioning Nutrition as Central to Development: A Strategy for Large-Scale Action." 36 In the study, the Bank emphasized the importance of nutrition to economic development and hence to the fulfillment of its own mandate, stating that "improving nutrition is as much — or more - an issue of economics as one of welfare, social protection, and human rights." ${ }^{37}$ The report explicitly called on public and private actors within the international nutrition community to come together in support of one common nutrition agenda: supporting increased investment in evidence-based, cost-effective nutrition interventions in a selection of highly burdened countries.

Two coalitions that promoted competing nutrition paradigms gradually formed in response to this investment agenda. ${ }^{38}$ The coalition supportive of the World Bank's agenda, the micronutrient investment coalition (hereafter the investment coalition), ${ }^{39}$ was endowed with considerable public and private funding, providing instrumental power to promote its technical agenda. It included most of the members of GAIN; namely, the Gates Foundation, the World Bank, U.S. and Canadian aid agencies, global food corporations such as Royal DSM, large nongovernmental organizations (NGOs) such as Helen Keller International (HKI), as well as the UN Children's Fund (UNICEF) and the World Food Programme (WFP). ${ }^{40}$ Altogether, this

35. Bhagwati et al. 2004.

36. World Bank 2006.

37. World Bank 2006, 2.

38. These did not exist as formal coalitions, but as two groups of actors representing distinct views and interests on matters of nutrition governance. The coalitions' names have been invented by the author.

39. Jonsson 2010.

40. World Bank 2010. 
coalition represented private sector interests promoting food fortification and micronutrient supplements as the most cost-effective way to deal with undernutrition — an approach most actors in the coalition also had a stake in, either as producers or providers of fortified food or micronutrient supplements.

Conversely, members of the other coalition promoted a human rights and food-based approach to nutrition, which it saw as necessary to address the underlying causes of malnutrition. ${ }^{41}$ This human right to nutrition coalition (hereafter HR coalition) had less financial resources, and hence instrumental power, to promote its agenda. It included no private actors, but smaller civil society organizations (CSOs) such as the International Baby Food Action Network (IBFAN), European donors such as France and the European Commission (EC), and the member state-mandated UN agencies - the UN Food and Agriculture Organization (FAO) and the WHO. Common for these actors were their reliance on public funding, their commitment to human rights as the basis for development, and their belief in the need to address the underlying structural causes of undernutrition, as well as their more critical stance toward private sector inclusion in nutrition policy making. An overview of the main actors within the two coalitions can be found in table 1 below.

41. Jonsson 2010. 
Table 1 Overview of the main actors within the two coalitions

\begin{tabular}{|c|c|c|}
\hline & $\begin{array}{l}\text { Micronutrient investment } \\
\text { coalition }\end{array}$ & $\begin{array}{l}\text { Human right to nutrition } \\
\text { coalition }\end{array}$ \\
\hline \multirow[t]{3}{*}{ UN agencies } & $\begin{array}{lll}\text { UN } & \text { Children's } & \text { Fund }\end{array}$ & Food and Agriculture \\
\hline & (UNICEF) & Organization (FAO) \\
\hline & $\begin{array}{l}\text { World Food Programme } \\
\text { (WFP) }\end{array}$ & $\begin{array}{l}\text { World Health Organization } \\
\text { (WHO) }\end{array}$ \\
\hline \multirow[t]{3}{*}{ Public and private donors } & United States $(3,674,248)$ & $\begin{array}{l}\text { European Commission (EC) } \\
(429,977)\end{array}$ \\
\hline & Canada $(110,333)$ & France $(26,925)$ \\
\hline & $\begin{array}{l}\text { World Bank }(1,982,984)^{\mathrm{a}} \\
\text { Gates Foundation }(62,380)\end{array}$ & Germany $(23,654)$ \\
\hline $\begin{array}{l}\text { Civil society organizations } \\
\text { (CSOs)/nongovernmental }\end{array}$ & $\begin{array}{l}\text { Médecins Sans Frontières } \\
\text { (MSF) }\end{array}$ & $\begin{array}{l}\text { Food First Information and } \\
\text { Action Network (FIAN) }\end{array}$ \\
\hline \multirow[t]{3}{*}{ organizations (NGOs) } & $\begin{array}{l}\text { Helen Keller International } \\
(\mathrm{HKI})\end{array}$ & $\begin{array}{l}\text { International Baby Food } \\
\text { Action Network (IBFAN) }\end{array}$ \\
\hline & $\begin{array}{l}\text { Micronutrient International } \\
\text { (MI) }\end{array}$ & $\begin{array}{l}\text { Peoples Health Movement } \\
\text { (PHM) }\end{array}$ \\
\hline & Bread for the World & \\
\hline \multicolumn{3}{|c|}{$\begin{array}{l}\text { Notes: This table is the author's. It does not provide a precise representation of reality, as } \\
\text { most actors did not take an either-or view but disagreed about the extent to which market- } \\
\text { based approaches should be at the core of a new nutrition agenda. Some actors, such as the }\end{array}$} \\
\hline \multicolumn{3}{|c|}{ United Kingdom and Ireland, tried to represent the middle ground, balancing the two } \\
\hline
\end{tabular}


a. Total commitments for 2010, as numbers for actual spending are not available (IFPRI 2014).

\subsection{Contestations over Institutional Responses to Undernutrition: The Role of the Private}

\section{Sector and the UN}

While the HR coalition had less instrumental power to promote its agenda than the investment coalition, the HR coalition endowed structural power through its representation in the UN Standing Committee on Nutrition (UNSCN). Established in 1977, UNSCN was a global harmonizing platform for nutrition concepts, policies, strategies, and programs across UN agencies. ${ }^{42}$ Members of the committee were thus highly influential in shaping the global nutrition agenda. In the mid-2000s, in addition to a secretariat and a steering committee, UNSCN was organized into three constituencies: UN system agencies, civil society/academics, and bilateral donors. Private sector actors, such as the food industry and philanthropic foundations, were not represented. While UNSCN served as an important platform for collaboration across its constituencies, many actors in the investment coalition considered it ineffective and as a talking shop. The role of the food industry was a particular source of controversy and, on this issue, UNSCN became "an open battleground" between representatives of the two coalitions. ${ }^{43}$

In 2006 the WFP and UNICEF, members of UNSCN and belonging to the investment coalition, proposed the establishment of a new nutrition initiative called the Global Framework for Action for Ending Child Hunger and Undernutrition Initiative (ECHUI) that aimed to attract private sector funding into nutrition. ${ }^{44}$ According to former WFP and FAO staff members and

42. Longhurst 2010.

43. Longhurst $2010,390$.

44. WFP and UNICEF 2006; Mokoro 2015b. 
a former representative of the UNSCN Civil Society Constituency, the HR coalition did not support the initiative for several reasons. First, FAO and the WHO did not like to be excluded from any global initiative for nutrition. Second, many questioned the rationale of establishing an additional structure to UNSCN. Third, ECHUI was viewed as being too top down and too focused on technical interventions at the expense of food and human rights-based approaches. Many also feared that private sector involvement would undermine the UN's independence and integrity, and divert resources away from long-term solutions to undernutrition. Several interviewees recalled that tension arose as academic and civil society human rights promoters tried to push UNSCN into what they called an "anti-private sector direction." The often fierce resistance toward the private sector was not conducive to collaboration. As expressed by a Gates Foundation representative, "We had no place in it [UNSCN], we had no voice in it, and we were treated poorly by the main voices of SCN that were accountable, in our opinions, to no one." 45

While the membership of UNSCN at the time delayed efforts to open up global nutrition governance to the private sector, actors in the investment coalition soon came to strengthen their relative influence in UNSCN. In 2006, UNICEF director Ann Veneman took over the revolving chairmanship of the UNSCN steering committee, strengthening UNICEF's ability to influence the destiny of the committee and, hence, the structural power of the investment coalition. Under UNICEF's leadership, the UNSCN's steering committee commissioned a review of the organization to "improve the functioning of the SCN."46 Members of the Civil Society Constituency expressed strong dissatisfaction with the chair, who they found to be promoting the food industry's interests, and with the review, claiming that it was not transparent

45. Gates Foundation representative, interviewed by the author, Milan, 21 October 2015. 46. UNSCN 2008. 
and out of touch with UNSCN members' opinions. ${ }^{47}$ However, despite resistance, the chair, with the support of members of the investment coalition, was able to put the reform in motion. The reform was facilitated by UNSCN's dependence on funding from investment coalition members. The World Bank, which for years had been one of the main funders of UNSCN, significantly reduced its contribution in 2006/2007, and stopped it completely in 2008/2009. The WFP and UNICEF also reduced their funding in this period. ${ }^{48}$ As a result of the reform, the UNSCN annual sessions, which had served as the main forum for discussion across the constituencies, were disbanded after 2008, and UNSCN was eventually transformed from a "tripartite" structure into a UN agency-only coordination committee, effectively reducing the influence, and structural power, of critical civil society voices from the HR coalition. ${ }^{49}$

Given UNSCN's dependence on funding from members of the investment coalition, these members' withdrawal of funding exemplifies how instrumental power enabled the effective exercise of structural power as they influenced the reform process, weakening opposition to their agenda. Flavio Valente claims that the reviews and withdrawal of support to UNSCN were instrumental for what later led to the establishment of SUN: "SUN occupied a vacuum created by the 'reforming' and subsequent curtailing of [UN]SCN activities.

Curiously, the international organizations and funds that withdrew support, such as the World Bank, UNICEF, and WFP, were the ones that later launched SUN."50

The Gates Foundation and the World Bank were particularly instrumental in weakening UNSCN's position and building support for a new private sector-friendly nutrition initiative. Their influence was derived from a combination of instrumental and discursive

47. UNSCN Civil Society Constituency 2008.

48. Longhurst 2010; UNSCN 2016.

49. Friel, 2017, 22.

50. Valente 2015, 16-17. 
power: while they used their economic resources to lobby policymakers and potential investors to support their agenda, they also funded and disseminated scientific research that strongly contributed to shape public perceptions about what the appropriate solution and governance mechanism to improving nutrition should be. In 2008 the Gates Foundation funded the Lancet Series on Maternal and Childhood Undernutrition, and a new World Bankinfluenced Copenhagen Consensus Report on the economics of hunger and malnutrition was published. ${ }^{51}$ The research contributed to strengthen the investment coalition's agenda as it provided new scientific support for scaling up investments in technical nutrition interventions during the first 1,000 days of a child's life. One of the papers in the Lancet Series also reviewed the effectiveness of global nutrition governance. It concluded that the international nutrition system was "fragmented and dysfunctional" and recommended the establishment of a "new global governance structure" 52 incorporating both civil society and the private sector. Coming from The Lancet, considered one of the most authoritative sources of knowledge in global health, ${ }^{53}$ the findings and recommendations embodied considerable discursive power, implying a scientific consensus on infant and child nutrition interventions. ${ }^{54} \mathrm{HR}$ coalition actors within UNSCN, particularly civil society, criticized the research for ignoring the underlying determinants of nutrition and downplaying the critical role played by the UN system in efforts to overcome undernutrition. ${ }^{55}$ While some of the criticism was acknowledged, and a follow-up series was published in 2013 looking more broadly at the

51. Bhutta et al. 2008; Horton, Alderman, and Rivera 2008.

52. Morris, Cogill, and Uauy 2008, 82.

53. Shiffman 2014.

54. Mokoro 2015a, 6.

55. UNSCN 2008, 14. 
causes of undernutrition, ${ }^{56}$ the 2008 series was used by the investment coalition as an instrument to create support for its agenda. A representative of the Gates Foundation explained how the foundation and the World Bank actively worked to mobilize support "around a common set of baseline evidence" $" 57$ as they lobbied politicians at high-level events such as at the Group of 8 (G8) summits in 2008 and 2009, and convened high-level conferences such as the 2008 Pacific Health Summit, to attract investment and interest from donors. ${ }^{58}$ The Gates Foundation also commissioned a research report on how to follow up on the recommendations from the Lancet paper on global nutrition governance, the findings of which were in line with its agenda. The report contained a damning analysis of UNSCN: "[UNSCN] is widely observed to have failed to harmonize priorities and practices across the UN system and more broadly among the nutrition sector.... No one ... thinks that it has the legitimacy or technical and political strength to serve the function for nutrition that UNAIDS does in its field." 59 This report, as with the Lancet Series, contributed to legitimize the investment coalition's effort to replace UNSCN with a new nutrition initiative.

Subsequently, in 2009 the World Bank started to lead the development of a Global Action Plan for Scaling Up Nutrition Investments (GAP) ${ }^{60}$ Interviewees involved in its development explained how two World Bank-funded consultants drove the process, building on a number of consultations organized in collaboration with the Gates Foundation and the US Agency for International Development (USAID) in the aftermath of the Lancet Series publication. Actors initially involved in the development of GAP also included UNICEF, the

56. "Maternal and Child Nutrition" 2013.

57. Gates Foundation representative interview.

58. NBAR 2008, 15.

59. Levine and Kuczynski 2009, 11.

60. Bezanson and Isenman 2009, 2. 
WFP, HKI, Micronutrient International (MI), Save the Children, and the Center for Global Development. ${ }^{61}$ The primary rationale of GAP was to "create a movement and a mechanism to ... scale-up nutrition, and to contribute towards a pragmatic vision and common agenda" that would promote investment in "evidence-based, high-priority nutrition interventions" within a set of priority countries. ${ }^{63}$ The Gates Foundation representative explained that the idea was that GAP should not be "UN centric," but multistakeholder. Unlike UNSCN, it should be “inclusive as opposed to exclusive — aligning around a common agenda as opposed to infighting about which issue which was most important." ${ }^{, 64}$

Disagreement thus arose concerning the UN's role: Should it be the leader or merely a stakeholder among others in the new nutrition initiative? The tension had become clear when the reformed ECHUI initiative, renamed Renewed Efforts Against Child Hunger and Undernutrition (REACH) was presented in $2008 .{ }^{65} \mathrm{UNICEF}$, the WFP, the WHO, and FAO all supported the initiative, which included the private sector but was led by governments and the UN. ${ }^{66}$ A former staff member of the UNSCN secretariat explained that donors within the investment coalition preferred GAP, not REACH, to become the "embryo for solid nutrition governance" and that they "supported a mechanism where the UN was equal to other players, private sector included." ${ }^{, 67}$ Furthermore, the donors did not want an open mechanism, but preferred to limit participation to countries they selected.

61. World Bank 2009.

62. World Bank 2009, 3.

63. Bezanson and Isenman 2009, 2.

64. Gates Foundation representative interview.

65. UNSCN 2008.

66. UNSCN 2008, 8.

67. Former staff member of the UNSCN secretariat, interviewed by the author via telephone, 16 November 2015. 
Therefore, as Table 2 summarizes, the nutrition community was sharply divided over the way to address undernutrition and over how power should be distributed within a new global nutrition initiative.

Table 2 Main lines of contestation within the international nutrition community

\begin{tabular}{|c|c|c|}
\hline Issues of contestation & $\begin{array}{l}\text { Micronutrient investment } \\
\text { coalition }\end{array}$ & $\begin{array}{l}\text { Human right to nutrition } \\
\text { coalition }\end{array}$ \\
\hline Framing of the issue of & Invest in nutrition/nutrition & Human right to \\
\hline \multirow[t]{5}{*}{ undernutrition } & for economic growth & food/nutrition \\
\hline & Instrumental framing & Intrinsic framing \\
\hline & Technology dominated & Ethics dominated \\
\hline & Evidence based & Rights based \\
\hline & Positivistic & Normative \\
\hline Types of solutions & Technical- and product-based & Human rights and food-- \\
\hline \multirow[t]{4}{*}{ promoted } & approaches focusing on & based approaches addressing \\
\hline & reducing undernutrition & underlying causes of \\
\hline & directly through food & malnutrition across different \\
\hline & supplementation/fortification & sectors \\
\hline View on the role of & Necessary, win-win, bring & To be kept out of decision- \\
\hline business in global nutrition & technology and resources, & making processes to avoid \\
\hline governance & increase efficiency & undue influence \\
\hline
\end{tabular}


View on the role of the

state in global governance

View on the role of the UN
Share authority with nonstate

actors

Bureaucratic, dominated by

civil society and not inclusive

enough of business
Governments have supreme

decision-making power

Necessary, most democratic

and legitimate source of

authority at the global level

Note: Author's table.

\subsection{The SUN Rises: A Solid Consensus or a Shaky Compromise?}

While a stalemate seemed to be forming between the two coalitions, an external event helped forge some sort of compromise, giving rise to SUN. In 2008, a global food price crisis had exposed significant dysfunctions in global food governance. ${ }^{68}$ As a response, a number of donors, including the United Kingdom, Ireland, and the European Commission, stepped up their support to food security and nutrition, and several new food security and nutrition initiatives were established such as the UN High-Level Task Force on the Global Food Security Crisis (HLTF). ${ }^{69}$ The UN Secretary-General tasked David Nabarro, UN special representative on food security and nutrition and head of HLTF at the time, with improving coordination of the international nutrition system. In November 2009, he attended a high-level meeting on "Recapturing Malnutrition Reduction" in Brussels, jointly organized by UNSCN and the EC to discuss policy coherence and nutrition architecture. ${ }^{70}$ With representatives from both coalitions attending, the festering disagreements between the two came out into the open. One attendant described what went on as a "tribal fight": "So at the Brussels meeting, stimulated by The

68. McKeon 2015.

69. McKeon 2015.

70. UNSCN 2009. 
Lancet Series, group A, which is the World Bank plus Gates . . plus perhaps USAID, plus quite a lot of academics, plus GAIN, saying we got to get moving. And side B led by the European Commission and France, . . . there was a really good tribal fight. A lot of nastiness."

Civil society representatives within the HR coalition, and FAO in particular, criticized GAP for being too top down and for lacking a human rights and food-based approach. One donor representative, however, argued that GAP was not supported because UN agencies considered the World Bank to be "stepping into their territory" and because civil society had "paranoia of working with the private sector." "72 Whatever the reasons, it became clear that GAP did not have enough support to fly in its current form and, according to the same interviewee, the World Bank decided to let the Gates Foundation, considered a more "trusted" partner, drive the agenda. At this time, FAO took over the UNSCN chairmanship from UNICEF, effectively regaining some of the influence and structural power of the HR coalition. ${ }^{73}$ With increased financial support from European donors, such as Ireland and the EC, the UNSCN secretariat was tasked at the Brussels meeting with leading "a consultative strategy process at country and global level to develop an approach to scaling up nutrition" and to "be a forum to fill the gaps in the GAP.",74

Also behind this consultative process was Nabarro, who played a crucial role in getting the two sides to meet. As representative of the highest UN authority, not representing any one side, Nabarro was seen as a trusted and legitimate partner for both coalitions. His high-level position gave him structural power to influence the process, aiming, in his words: "to create a

71. Senior UN official, interviewed by the author, Geneva, 12 November 2015.

72. Donor representative, interviewed by the author, Milan, 20 October 2015.

73. Longhurst 2010.

74. UNSCN 2009, 9. 
neutral space where the two sides could co-exist." ${ }^{75} \mathrm{He}$ was also able to influence the discourse on nutrition as he contributed to reframe GAP's focus more toward country ownership, food security, and the underlying causes of undernutrition. ${ }^{76}$ In collaboration with UNSCN and UNICEF, among others, he advanced a dual perspective on undernutrition, emphasizing both "nutrition specific" (technical) and "nutrition sensitive" (cross-sectoral) interventions as equally important.

As the process was opened up for inputs from a broader variety of actors, GAP was eventually developed into a multipartner global Framework for Action for Scaling Up Nutrition, endorsed in 2010 by more than eighty public and private donors, NGOs, and academic institutions. ${ }^{77}$ Now, tensions erupted, however, over where the initiative should be based. A donor representative noted how especially the WFP, but also GAIN, wanted to host the new initiative even though it was not supposed to "belong to anyone."78 Despite lack of official endorsement from all the UN agencies, the World Bank decided to launch the new framework at its joint spring meeting with the International Monetary Fund (IMF) in April 2010. ${ }^{79}$ To draw the initiative back within the UN realm, the following month the WFP hosted a nutrition forum in Rome that launched the founding document of the SUN Movement: "Scaling Up NutritionA Framework for Action." ${ }^{80}$ This framework had eventually been endorsed by all the UN agencies, including FAO. At this meeting, Nabarro accepted the role of coordinating efforts to build a "global nutrition movement," soon to become the Scaling Up Nutrition Movement. ${ }^{81}$

75. David Nabarro, interviewed by the author, Geneva, 12 November 2015.

76. Nabarro 2010.

77. World Bank 2010.

78. Donor representative interview.

79. Donor representative interview.

80. WFP 2010.

81. WFP 2010. 
While a common framework was finally endorsed, not everyone was satisfied with the turn that things had taken. Many actors within the investment coalition were reportedly disappointed by the fact that the UN and Nabarro now seemed to have taken over the steering wheel. The private sector, in particular, thought there "was too much UN in the place." 82 Thus, despite a certain compromise around a common framework, tensions lingered concerning the UN's role. UNSCN Civil Society Constituency members were not satisfied either, claiming that the SUN framework paid too little attention to human rights. ${ }^{83}$ Nevertheless, in collaboration with the UNSCN secretariat, Nabarro was able to carry the work forward. By September 2010, he had established a multistakeholder Task Team as an interim stewardship arrangement, which adopted a "Road Map for Scaling Up Nutrition."

UNSCN's role, however, continued to be controversial. Nabarro actively drew on the UNSCN secretariat's support, which played a crucial behind-the-scenes role in developing the SUN framework, and in mobilizing support within its network of developing country governments, marginally involved so far. ${ }^{85}$ As the UNSCN's then executive secretary put it in 2010, "It is important to note that we, from the UNSCN Secretariat, provided continuous and solid support to this process in a low-profile way and in the background. We knew that many of the SUN stakeholders did not want to see the UNSCN as a core player in this process, but we believed in its [SUN's] potential and thought that helping was the right thing to do." 86

82. Senior UN official, interviewed by the author, Geneva, 12 November 2015.

83. Cannon et al. 2010.

84. SUN 2010; UNSCN 2010.

85. UNSCN 2010.

86. UNSCN 2010, 26. 
Many donors from the HR coalition, particularly the EC, France, and Germany, supported SUN but saw the need to place it within UNSCN to provide an institutional home and, as a German representative said, "make it really legitimate." ${ }^{87}$ Nabarro also seemed to recognize the need to keep UNSCN involved to strengthen support for SUN: "there was discussion about whether or not having a Transition Team that was not anchored in some kind of global institution was legitimate. Then, it was clear we needed to link together the UNSCN Secretariat and a number of other stakeholders in order to make sure that we had a way of moving forward." 88

The UNSCN's secretariat contributed as such to mobilize support from both coalitions, facilitating the establishment of SUN. However, while Nabarro was trying to forge a compromise, powerful actors in the investment coalition continued to steer developments in line with their own interests. Donors within the investment coalition, still determined to establish a partnership outside of any UN entity, used (as before) their instrumental power to exercise discursive power through the funding of research shaping perceptions of possible governance options. An interviewee from the SUN secretariat explained how the US-based donors decided to resolve the question about SUN's institutional status by commissioning a Stewardship Study to be undertaken by the two consultants who had produced GAP. The EC, which wanted to have a say as well, funded a third consultant to contribute to the study. ${ }^{89}$ The resulting study was a catastrophe for UNSCN, and a former staff member of the UNSCN secretariat claimed it was highly biased in favor of placing SUN outside of UNSCN. Based on

87. UNSCN 2010, 28.

88. UNSCN 2010, 23.

89. Isenman, Bezanson, and Gostelow 2011. 
a survey and interviews with actors mainly representing the investment coalition, ${ }^{90}$ the study recommended that SUN should continue independently of UNSCN. SUN should thus be placed above UN agency level, the study said, and its leadership group should "be multi-stakeholder rather than controlled by the UN or any other stakeholder." 91

Despite opposition from the UNSCN secretariat, Nabarro and an interim SUN Transition Team, consisting mainly of actors from the investment coalition - the World Bank, the Gates Foundation, Canada, GAIN, Bread for the World, Médecins Sans Frontières (MSF), the New Partnership for Africa's Development, and government and academia representatives from Thailand, India, and Malawi-moved forward with the Stewardship Study's recommendations. ${ }^{92}$ This paved the way for SUN to become a new GPPP for undernutrition outside of UNSCN and any of the UN agencies.

A SUN secretariat was subsequently established in Geneva with Nabarro continuing as coordinator (until 2014), and four global networks representing business, donors, the UN, and civil society were created. Actors from the investment coalition came to take, and still play, a dominant role within the partnership, effectively strengthening their influence in global nutrition governance. Since 2012, UNICEF's executive director has chaired SUN's advisory Lead Group, while the Gates Foundation has chaired the executive committee together with a representative of a SUN member country since $2016 .{ }^{93}$ GAIN and the WFP cofacilitate the SUN Business Network and have effectively transformed GAIN's former Business Alliance into the SUN Business Network, which today represents more than 300 companies including the

90. Isenman, Bezanson, and Gostelow 2011, 28-30. (Attachments on 26-96 have not been made available in the published online version of the report.)

91. Isenman, Bezanson, and Gostelow 2011, 14.

92. Isenman, Bezanson, and Gostelow 2011, 28-30.

93. SUN, 2015. 
world's largest food and agriculture corporations. ${ }^{94}$ Most of the critical civil society organizations within UNSCN have decided not to join the SUN Civil Society Network, which remains dominated by large international NGOs from the investment coalition. ${ }^{95}$ While UNSCN survived and is today slowly reviving under FAO's hosting, its functions and funding remain limited, and many question its role as it now operates in parallel to the SUN UN Network whose secretariat also acts as the REACH secretariat hosted by the WFP. ${ }^{96}$ A simplified representation describing the institutional development of SUN can be found in figure 1 below.

Figure 1 Simplified overview of the institutional development of SUN

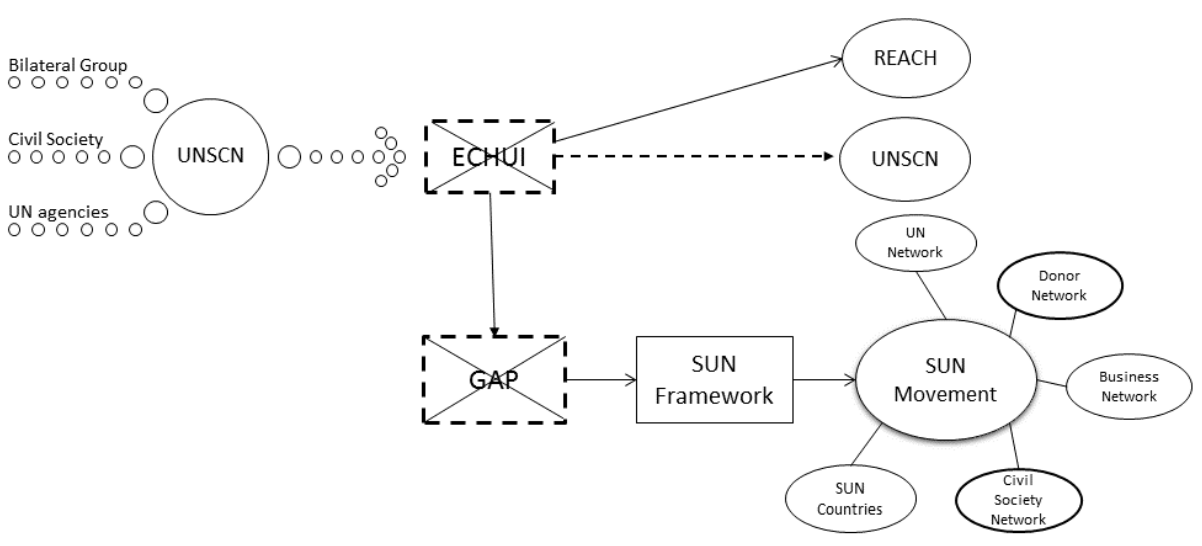

94. SUN Business Network 2017.

95. SUN Civil Society 2017.

96. SUN UN Network,2015. 
Note: Figure 1 is the author's representation of SUN's development. SUN, Scaling Up Nutrition; UNSCN, UN Standing Committee on Nutrition; ECHUI, Global Framework for Action for Ending Child Hunger and Undernutrition Initiative; GAP, Global Action Plan for Scaling Up Nutrition Investments; REACH, Renewed Efforts Against Child Hunger and Undernutrition.

\section{Discussion and Conclusion}

In this article, I unpacked the politics of unequal power relations on which SUN is built and demonstrated how state and nonstate actors exercise instrumental, structural, and discursive power behind the scenes through the use of visible and less visible means at the global political arena. While the SUN framework represented a sort of compromise between two competing coalitions, ultimately, actors of the coalition supporting private sector involvement tipped the balance in their favour as they used their influence to develop SUN into a GPPP, effectively side-lining an existing UN nutrition structure, as well as critical civil society voices.

As I showed, the distinction between instrumental, structural, and discursive power helps us to better understand the complexities and multifaceted ways that both state and nonstate actors seek to influence formal policy and governance frameworks that set the rules of the game at the global political arena. During the processes of SUN's creation, different forms of power were clearly at play, overlapping and reinforcing each other in complex ways. The developments show how instrumental power played a particularly significant role, enabling the micronutrient investment coalition to wield structural and discursive power to advance its agenda. Actors in the investment coalition exercised instrumental power when they used its financial resources to lobby decision-makers and to hire consultants advancing its interests. Indirectly, its instrumental power enabled it to gain structural power, as it withdrew much- 
needed funding from UNSCN, eventually leading to its reform. By exercising instrumental power, the investment coalition also strengthened its discursive power as it funded influential research shaping perceptions about "appropriate" nutrition interventions and governance responses in line with its agenda. The World Bank and the Gates Foundation were particularly successful in pursuing their agenda by using their resources to amplify scientific knowledge underpinning beliefs in economic growth and technology as solutions to the problem of undernutrition. However, actors from the HR coalition challenged their influence, questioning the validity of their message and the private sector's legitimacy. Instead, it promoted democratic and human rights ideals, and defended the delegated rational-legal and moral authority of UNSCN. With limited instrumental power, it was less successful in promoting its agenda, although the structural power of Nabarro contributed to promote a more holistic approach to the nutrition problem.

Whether SUN has reduced the level of fragmentation within global nutrition governance is questionable as its establishment increased the number of global coordinating entities for nutrition, strengthened divisions within civil society, and blurred responsibilities between public and private actors in the field. While SUN describes itself as a country-led effort, developing countries were minimally involved and had little, if any, influence over its establishment. SUN has over time become inclusive of developing countries; however, powerful actors from the investment coalition still dominate its governance. Indeed, as critics suggest, SUN has certainly opened the space for private sector influence in global nutrition governance and is today contributing to the promotion of market- and technology-based solutions to nutrition problems. ${ }^{97}$ While corporations were not the main drivers behind the partnership, states, international organizations, and private actors believing in the private sector as an effective motor of development and legitimate player in global governance stood behind 
SUN's creation. The diversity of actors behind SUN is not unique in the larger context of GPPP creation, and exemplifies the complexities behind the proliferation of partnerships and increased institutionalization of private sector interests in global governance. ${ }^{98}$ The focus on the power dynamics behind SUN's creation shows nevertheless how GPPPs may reinforce the interests of powerful private actors while challenging democratic ideals as the norm of good global governance. This article provides as such an important commentary on the development of GPPPs, demonstrating how GPPPs as a favored form of global governance is highly political and far from a value neutral process, involving battles over problem definition, solutions, and governance options.

98. Andonova 2017, 202; Storeng and Behague 2016. 


\section{Bibliography}

Andonova, Liliana B. Governance Entrepreneurs: International Organizations and the Rise of Public-Private Partnerships (New York: Cambridge University Press, 2017).

Barnett, Michael, and Raymond Duvall, eds. Power in Global Governance (Cambridge: Cambridge University Press, 2005).

Bezanson, Keith, and Paul Isenman. "Moving toward Consensus: A Global Action Plan for Scaling Up Nutrition.” Policy Brief ( Draft, November 2009).

www.unscn.org/files/Annual_Sessions/2009_Brussels/GAPpolicybrief_newcover.doc.

Bhagwati, Jagdish, et al. "Ranking the Opportunities.", Part II, pp. 605 - 645 in Global Crises, Global Solutions, ed. Bjorn Lomborg (Cambridge: Cambridge University Press, 2004).

Bhutta, Zulfiqar A., Tahmeed Ahmed, Robert E. Black, Simon Cousens, Kathryn Dewey, Elsa Giugliani, Batool A. Haider, et al. "What Works? Interventions for Maternal and Child Undernutrition and Survival.” The Lancet, 371(9610) (2008), 417-440.

Geoffrey Cannon, Wenche Barth Eide, Asbjorn Eide, Catherine Geissler, Ted Greiner, Elisabet Helsing et al., "Open Letter to the SCN Steering Committee” (21 April 2010).

Clapp, Jennifer, and Doris Fuchs, eds. Corporate Power in Global Agrifood Governance (Cambridge: MIT Press, 2009).

Clapp, Jennifer, and Gyorgy Scrinis. "Big Food, Nutritionism, and Corporate Power." Globalizations 14 (4) (2016), 578-595.

Fejerskov, Adam. "The New Technopolitics of Development and the Global South as a Laboratory of Technological Experimentation." Science, Technology, and Human Values 42 (5) (2017), 947-968. 
Friel, Sharon. "Global Governance for Nutrition and the Role of UNSCN.” Discussion Paper. United Nations System Standing Committee on Nutrition, March, Rome: Italy, (2017).Available at: https://www.unscn.org/uploads/web/news/document/GovernPaper-ENmay17-WEB.pdf

Fuchs, Doris. "Commanding Heights? The Strength and Fragility of Business Power in Global Politics.” Millennium: Journal of International Studies 33 (3) (2005), 771-801.

Fuchs, Doris, and Katharina Glaab. "Material Power and Normative Conflict in Global and Local Agrifood Governance: The Lessons of 'Golden Rice' in India.” Food Policy 36 (6) (2011), 729-735.

Fuchs, Doris, and Markus M.L. Lederer. “The Power of Business.” Business and Politics 9 (3) (2007), 1-17.

GAIN (Global Alliance for Improved Nutrition). "SUN Nutrition Hub” (2018). https://www.gainhealth.org/knowledge-centre/event/the-sun-nutrition-hub-how-can-westrengthen-the-enabling-environment-for-business-to-take-action-in-improving-nutrition/.

Gillespie, Stuart, Milla McLachlan, and Roger Shrimpton. “Combating Malnutrition: Time to Act" (Washington, DC: World Bank, 2003).

Haddad, Lawrence, Harold Alderman, Simon Appletan, Lina Song, and Yisehac Yohannes. "Reducing Child Malnutrition: How Far Does Income Growth Take Us?” World Bank Economic Review 17 (1) (2003), 107-131.

Hanefeld, Johanna, and Gill Walt. "Knowledge and Networks: Key Sources of Power in Global Health; Comment on 'Knowledge, Moral Claims and the Exercise of Power in Global Health." International Journal of Health Policy and Management 4 (2) (2015), 119-121.

Harman, Sophie. "The Bill and Melinda Gates Foundation and Legitimacy in Global Health Governance.” Global Governance 22 (3) (2016), 349-368. 
Hoddinot, John, Stuart Gillespie, and Yosef Sivan. "Public-Private Partnerships and the Reduction of Undernutrition in Developing Countries." Discussion Paper 01487 (International Food Policy Research Institute [IFPRI], Washington, DC., 2015).

Horton, Sue, Harold Alderman, and Juan A. Rivera. "Copenhagen Consensus 2008 Challenge Paper: Hunger and Malnutrition” (Copenhagen: Copenhagen Consensus Center, 2008).

IFPRI (International Food Policy Research Institute). "Global Nutrition Report 2014: Actions and Accountability to Accelerate the World's Progress on Nutrition" (Washington, DC: IFPRI, 2014).

Isenman, Paul, Keith Bezanson, and Lola Gostelow. "Stewardship of the SUN Movement: Taking SUN to the Next Level" (SUN, 30 September 2011). http://docs.scalingupnutrition.org/wp-content/uploads/2016/11/Stewardship-Study-FinalReport.pdf.

Jonsson, Urban. "The Rise and Fall of Paradigms in World Food and Nutrition Policy." Commentary. World Nutrition 1 (3) (2010), 128-158.

Kraak, Vivica, Paige B. Harrigan, Mark Lawrence, Paul J. Harrison, Michaela A. Jackson \& Boyd Swinburn "Balancing the Benefits and Risks of Public-Private Partnerships to Address the Global Double Burden of Malnutrition.” Public Health Nutrition 15 (3) (2011), 503-517.

Levine, Ruth, and Danielle Kuczynski. "Global Nutrition Institutions: Is There an Appetite for Change?” (Washington, DC: Center for Global Development, 2009).

Longhurst, Richard. “Global Leadership for Nutrition: The UN's Standing Committee on Nutrition (SCN) and Its Contributors.” IDS Discussion Paper No. 390 (Brighton: Institute of Development Studies [IDS], 2010).

“Maternal and Child Nutrition." Series from the Lancet journals. The Lancet (6 June 2013). http://www.thelancet.com/series/maternal-and-child-nutrition 
McDougall, Lori. "Power and Politics in the Global Health Landscape: Beliefs, Competition and Negotiation among Global Advocacy Coalitions in the Policy-Making Process." International Journal of Health Policy and Management 5 (5) (2016), 309-320.

McKeon, Nora. Food Security Governance: Empowering Communities, Regulating Corporations (Oxon, England: Routledge, 2015).

McKeon, Nora. "Are Equity and Sustainability a Likely Outcome when Foxes and Chickens Share the Same Coop? Critiquing the Concept of Multistakeholder Governance of Food Security." Globalizations 14 (3) (2017), 379-398.

Mokoro. "Independent Comprehensive Evaluation of the Scaling Up Nutrition Movement: Final Report-Main Report”(Oxford, England: Mokoro Ltd., 2015a).

Mokoro. "Strategic Evaluation: Joint Evaluation of Renewed Efforts against Child Hunger and Undernutrition (REACH) -2011-2015." Evaluation Report, Vol. 1, No. OEV/2015/026, World Food Program, Rome,(October 2015b). http://www.fao.org/3/a-bd907e.pdf.

Morris, Saul S., Bruce Cogill, and Ricardo Uauy. "Effective International Action against Undernutrition: Why Has It Proven so Difficult and What Can Be Done to Accelerate Progress?" The Lancet 371 (9612) (2008), 608-621.

Nabarro, David. "Introducing the Policy Brief 'Scaling Up Nutrition: A Framework for Action."” High-Level Nutrition Event, World Bank-IMF spring meetings, Washington, DC, April 2010. http://www.g20dwg.org/documents/pdf/view/65/.

Nabarro, David. Special adviser on the 2030 Agenda for Sustainable Development. Intervention at the inaugural meeting of the new Lead Group of the Scaling Up Nutrition Movement, New York, 21 September 2016. https://www.youtube.com/watch?v=efdDfeaLNlc.

NBAR (National Bureau of Asian Research). "The Global Nutrition Challenge: Getting a Healthy Start.” Report from the Pacific Health Summit, 16-18 June 2008. http://pacifichealthsummit.org/downloads/2008\%20Summit/2008\%20Summit\%20Report.pdf. 
Nisbett, Nicholas, Stuart Gillespie, Lawrence Haddad, and Jody Harris. "Why Worry about the Politics of Childhood Undernutrition?" World Development 64 (2014), 420-433.

Partzsch, Lena, and Doris Fuchs. "Philanthropy: Power with in International Relations." Journal of Political Power 5 (3) (2012), 359-376.

Richter, Judith. "Public-Private Partnerships for Health: A Trend with No Alternatives?" Development 47 (2) (2004), 43-48.

Sandberg, Kristin, Steinar Andresen, and Gunnar Bjune. “A New Approach to Global Health Institutions? A Case Study of New Vaccine Introduction and the Formation of the GAVI Alliance.” Social Science and Medicine 71 (7) (2010), 1349-1356.

Claudio Schuftan, and Ted Greiner. "The Scaling Up Nutrition (SUN) Initiative.”, pp. 22-23, in Right to Food and Nutrition Watch: Alternatives and Resistance to Policies that Generate Hunger, eds. Anne C. Bellows, Carolin Callenius, Christine Campeau, Marcos Arana Cedeño, Maarten Immink, Kathy McNeely, Stineke Oenema et al. (Bread for the World, FIAN International, and ICCO Cooperation, 2013).Available at: https://www.righttofoodandnutrition.org/files/Watch_2013_Full_Watch_ENG.pdf

Shiffman, Jeremy. "Knowledge, Moral Claims and the Exercise of Power in Global Health." International Journal of Health Policy and Management 3 (6) (2014), 297-299.

Shiffman, Jeremy, and Stephanie Smith. "Generation of Political Priority for Global Health Initiatives: A Framework and Case Study of Maternal Mortality.” The Lancet 370 (9595) (2007), 1370-1379.

Jeremy Shiffman, Hans Peter Schmitz, David Berlan, Stephanie L. Smith, Kathryn Quissel Uwe Gneiting and David Pelletier, "The Emergence and Effectiveness of Global Health Networks: Findings and Future Research.” Health Policy and Planning 31 (2016), i110-i123.

Stoeva, Preslava. "International Relations and the Global Politics of Health: A State of the Art." Global Health Governance 10 (3) (2016), 97-109. 
Storeng, Katerini T., and Dominique P. Behague. "Lives in the Balance: The Politics of Integration in the Partnership for Maternal, Newborn and Child Health." Health Policy and Planning, 31(8), (2016): 992-1000.

SUN (Scaling Up Nutrition). “A Road Map for Scaling Up Nutrition,” 1st ed. (September 2010).

http://siteresources.worldbank.org/NUTRITION/Resources/SUNRoadMapSeptember2010.pd f.

SUN. "Strategy at a Glance: 2016-2020" (2016). http://docs.scalingupnutrition.org/wpcontent/uploads/2016/09/strategy2016-in-a-second.pdf.

SUN. "How Is the Movement Supported.” (2015) http://scalingupnutrition.org/sunsupporters/how-is-the-movement-supported/.

SUN Business Network. "SUN Business Network Company Commitments" (9 January 2017). http://sunbusinessnetwork.org/wp-content/uploads/sites/2/2015/01/SUN-BusinessNetwork-Company-Commitments-09-Jan-2017.pdf.

SUN Civil Society Network. "List of Members" (2017).

http://www.suncivilsociety.com/documents/List_Of_Members_2017.pdf.

SUN UN Network. "Governance”, (2015). http://scalingupnutrition.org/sun-supporters/unnetwork-for-sun/.

UN Department of Public Information. "Press Conference by Global Alliance for Improved Nutrition (GAIN).”UN Special Session on Children, 9 May 2002.

https://www.unicef.org/specialsession/press/02bngain.htm.

UNSCN (UN Standing Committee on Nutrition). "Report of the Standing Committee on Nutrition at Its Thirty-Fifth Session.” (Hanoi: UNSCN, 3-6 March 2008). 
UNSCN. "Report on High Level Meeting on Nutrition" (Brussels: UNSCN and European Commission, 23-24 November 2009).

http://www.unscn.org/files/Annual_Sessions/2009_Brussels/Brussels_High_Level_Nutrition_ Meeting_report_final.pdf.

UNSCN. “UNSCN Nutrition Partners Kick-Off Meeting Report” (Rome: Food and Agriculture Organization [FAO], 14-15 December 2010.

http://www.unscn.org/files/Activities/Other_Meetings/UNSCN_kick_off_meeting_minutes_1 4_15_Dec_2010.pdf.

UNSCN. “UN Agency Contributions to UNSCN Core Budget 1994-2013.” UNSCN Secretariat Archive (November 2016).

UNSCN Civil Society Constituency. "NGO/CSO Report to the 35th SCN Meeting”March 6, 2008.

Utting, Peter, and Ann Zammit. "United Nations-Business Partnerships: Good Intentions and Contradictory Agendas.” Journal of Business Ethics 90 (2009), 39-56.

Valente, Flavio. "The Corporate Capture of Food and Nutrition Governance: A Threat to Human Rights and Peoples' Sovereignty.”, pp. 16-17, in Anne C. Bellows, Antonio Onorati, Bernhard Walter, Biraj Patnaik, Francisco Sarmento, Manigueuigdinapi J. S. Icaza, Marcos A. Cedeño et al. (eds), Right to Food and Nutrition Watch, Bread for the World, FIAN International and ICCO Cooperation, (2015). https://www.righttofoodandnutrition.org/files/R_t_F_a_N_Watch_2015_eng_singlepage_Web.pdf.

Valente, Flavio. "The Corporate Capture of Food and Nutrition Governance Revisited: A Threat to Human Rights and People's Sovereignty.” Colloquium Paper No. 62 (The Hague: International Institute of Social Studies, 2016).

WFP (World Food Programme). "Nutrition Forum.” (Rome: WFP and the City of Rome, 31 May-1 June 2010). http://www.unscn.org/files/Newsletters/Microsoft_Word__WFPNUTRITIONFORUM_SUNMTGOVERVIEW_AGENDA.pdf. 
WFP and UNICEF (UN Children's Fund). “Global Framework for Action: Ending Child Hunger and Undernutrition Initiative.” Revised Draft (December, 2006). https://www.unicef.org/about/execboard/files/Global_Framework_for_Action1.0-Dec2006.pdf.

WHO (World Health Organization). "New Global Alliance Brings Food Fortification to World's Poor." Global Alliance for Improved Nutrition (GAIN) press release, Durban, 12 June 2003. http://www.who.int/mediacentre/news/releases/2003/prgain/en/.

World Bank. "Repositioning Nutrition as Central to Development—A Strategy for Large Scale Action.” Directions in Development (Washington, DC: World Bank, 2006).

World Bank. “A Global Action Plan for Scaling-Up Nutrition Investments.” Draft outline. (Washington, DC: World Bank, 16 April 2009).

World Bank. "Scaling Up Nutrition: Report of a High-Level Meeting” (Washington, DC: World Bank, Canadian International Development Agency (CIDA), Japan, and US Agency for International Development [USAID], April 2010). http://documents.worldbank.org/curated/en/892361468059697624/Scaling-up-nutritionreport-of-a-high-level-meeting.

Youde, Jeremy. "Global Health Governance in International Society.” Global Governance 23 (4) (2017), 583-600. 